Potravinarstvo Slovak Journal of Food Sciences vol. 15, 2021, p. 784-791

https://doi.org/10.5219/1579

Received: 13 February 2021. Accepted: 5 September 2021. Available online: 28 September 2021 at www.potravinarstvo.com (C) 2021 Potravinarstvo Slovak Journal of Food Sciences, License: CC BY 4.0

ISSN 1337-0960 (online)

\title{
PHENOLIC CONTENT AND ANTIOXIDANT ACTIVITY OF ECHINOCYSTIS LOBATA (MICH.) TORR. ET GRAY (CUCURBITACEAE)
}

\author{
Yulia Vinogradova, Olga Shelepova, Olena Vergun, Olga Grygorieva, Ján Brindza
}

\begin{abstract}
Echinocystis lobata (Mich.) Torr. et Gray extracts were investigated for their bioactive compounds and their potential for natural antioxidant properties. In vitro antioxidant activity of methanol, ethanol, and water extracts were evaluated by 1,1-diphenyl-picrylhydrazyl (DPPH) radical scavenging activity. Total phenolic content (TPC) and total flavonoid content (TFC) of fruits and seeds were determined. TPC is a fairly constant value and varies weakly both among the different organs of Echinocystis lobata and among the geographical locations of the populations studied. Like other invasive species, Echinocystis lobata is superior to many other plants in terms of the total amount of flavonoids contained in its fruits and seeds. The dried fruits contain more flavonoids than the seeds. Seeds from Slovak populations have higher flavonoid content than those from Russian populations. The results demonstrated that Echinocystis lobata can be a good source of natural antioxidants and have a great potential for commercialization, especially in the pharmaceutical industry.
\end{abstract}

Keywords: Echinocystis lobata; leaves; flowers; fruits; seed; biological activity

\section{INTRODUCTION}

The secondary plant metabolites, polyphenols, have a wide spectrum of actions such as modulation of lipid peroxidation, free radical scavenging, inhibition of hydrolytic and oxidative enzymes (phospholipase A2, cyclooxygenase), and anti-inflammatory activity (Lu et al. 2016). The current focus is on the antioxidant activity of polyphenols. It is this activity that determines the pharmacological effects. Antioxidants play an important role in protecting human cells against free radicals, which cause several physiological and pathological abnormalities, such as cardiovascular disease, rheumatoid arthritis, cancer, and aging (Atanassova et al., 2011; Ghafar et al., 2017).

Scientists are constantly searching for plants whose organs contain substances with high antioxidant activity, namely Cydonia Mill. and Pseudocydonia C.K. Schneid. (Monka et al., 2014; Grygorieva et al., 2020), Cornus mas L. (Klymenko, Grygorieva and Brindza, 2017), Diospyros virginiana L. (Grygorieva et al., 2018), Sambucus nigra L. (Horčinová Sedláčková et al., 2018, 2019), Ziziphus jujuba Mill. (Ivanišová et al., 2017), Hippophae rhamnoides L. (Ivanišová et al., 2020), Lycium spp. (Szot, Zhurba and Klymenko, 2020). However, a whole group of invasive plants is little studied in this respect. Meanwhile, the secondary distribution range of invasive species expands year by year and their resource reserves in the new homeland are very large. Our previous studies have already demonstrated very high antioxidant activity in several invasive species: Aronia mitschurinii A.K.Skvortsov \& Maitul. (Vinogradova et al., 2017, 2020) and Solidago canadensis L. (Shelepova et al., 2020).

In this context, we began to study a North American Echinocystis lobata (Mich.) Torr. et Gray, which have been unintentionally introduced in Europe at the beginning of the XX century, no later than 1904, but had only isolated localities until World War II. From 1946 onwards, it gradually expanded its range and moved north-east. This species became established in Central and South-Eastern Europe, and the Far East, forming a secondary distribution range. The northern limit of the range in Russia runs along the line St. Petersburg - Vologda - Perm - Krasnoyarsk Irkutsk - Tynda - Komsomolsk-on-Amur (Vinogradova et al., 2010). Over the past 30 years, its secondary range has expanded considerably and the species has invaded natural riverine plant communities, becoming a "transformer" (Richardson and Pyšek, 2006). Invasive populations have been very stable: Echinocystis lobata actively displaces native riparian species from their habitats, producing a lot of seeds.

Echinocystis lobata belongs to the family Cucurbitaceae, and closely related species in the same family contain cucurbitacins that are used as antiproliferative, antiinflammatory, and antioxidant agents. Several species of this family, widely used in folk medicine, are now 
attracting the increasing attention of biochemists as valuable raw materials for new medicinal preparations. For example, the oil isolated from the seeds of Ecballium elaterium (L.) A. Rich. has antitumor activity and is promising for use in oncology (Touihri et al., 2019). The presence of cucurbitacins in seeds of the Cucurbitaceae family (and Echinocystis in particular) is known from the literature (Sokolov, 1986). All these compounds have a bitter, unpleasant taste, but can induce cytotoxicity against malignant cells in mammals (Panosyan, 1985) and are used to treat benign tumors and to kill worms (pumpkin seeds are known to have this pharmacological effect).

North American Indians use Echinocystis roots as a remedy: the bitterness extracted from the roots contains analgesics (Burton et al., 2015). Traditional medicine refers to its use for headaches, menstrual disorders, rheumatism, fever, kidney, or stomach problems (Melymuka et al., 2005). However, there is little scientific information on the composition of bioactive compounds of Echinocystis. There are indications of the presence of quercetin and isorhamnetin derivatives (KrauzeBaranowska and Cisowski, 1996). Various enzymes (Gillard and Walton, 1976) and trypsin inhibitors (Stachowiak et al., 1996) have been reported. The fruit contains carbohydrates: galactose, xylose, rhamnose, arabinose, and mucus (Budantsev and Lesiovskaya, 2014).

The presence in Echinocystis lobata of substances with a wide range of pharmacological effects, in particular, antitumor and antioxidant activity, increases interest in detailing the chemical composition of this species. Such studies may be promising and relevant, as they will allow evaluating the phytotherapeutic prospects of the plant and its resource potential.

Phenolic content and antioxidant activity have been studied in detail only in Romania. However, only the leaves, flowers, and above-ground parts of the plants have been studied; the seeds have not been examined. Ethanolic extracts from leaves and aerial parts of Echinocystis lobata contain mainly p-coumaric acid, isoquercitrin, rutin, quercitrin, and kaempferol (Ielciu et al., 2017). The flowers contained the same substances and in addition ferulic acid. Biological assays showed a significant antioxidant effect and no cytotoxic and anti-plasmodial activity (Ielciu et al., 2018).

When analyzing seeds of Echinocystis from geographically different populations of Central Russia, it was found that climatic and soil conditions of growth influence the accumulation of flavonoids - the total content of these compounds in the seeds of Echinocystis from the Moscow population was $0.085 \pm 0.005 \%$, and in seeds from the Tver population was $0.105 \pm 0.009 \%$. The flavonoid composition of seeds of this plant is practically not studied. Thus, only one literary source (KrauzeBaranowska and Cisowski, 1996) knows that Cglycosides are distinguished in flavonoid complex. Considering the significant content of flavonoids in the seeds of Echinocystis lobata and their undoubted importance in the biological activity of the raw material, furthermore, detailed study of the flavonoid composition of Echinocystis seeds seems to be advisable.

This work aims to compare the total content of polyphenols and flavonoids in different organs of Echinocystis in Central Russia and Slovakia.

\section{Scientific Hypothesis}

First, we assumed (based on our previous research on invasive species) that the Echinocystis lobata will have the same high levels of antiradical activity. Second, we believe that the content of beneficial substances will be higher in Slovak invasive populations, as the weather conditions here are more favorable for the growth of Echinocystis lobata.

\section{MATERIAL AND METHODOLOGY}

\section{Samples}

The material was collected from five sites in Russia and two sites in Slovakia (Table 1). The plants were collected in September 2019 during the fruiting season. Five to seven plants were selected from each population. Leaves, flowers, fruits, and seeds were studied (Figure 1,2).

\section{Chemicals}

All chemicals were analytical grade and were purchased from Reachem (Slovakia) and Sigma Aldrich (USA).

Table 1 Studied samples of Echinocystis lobata (Mich.) Torr. et Gray.

\begin{tabular}{|c|c|c|}
\hline Harvesting place & Geographical coordinates & Organ \\
\hline \multicolumn{3}{|c|}{ Russia } \\
\hline Zvenigorod, Moscow district, Russia & N 55.44 E 36.51 & $\begin{array}{c}\text { Leaves (ZL) } \\
\text { Flowers (ZFl) } \\
\text { Dry ripe fruit without seeds (ZF) } \\
\text { Dry unripe fruit with milk seeds (ZFS) } \\
\text { Seeds (ZS) }\end{array}$ \\
\hline Redkino, Tver district, Russia & N 56.38 E 36.17 & Seeds (TS) \\
\hline Kaluga, Russia & N $54.31 \quad$ E 36.15 & Seeds (KS) \\
\hline Uglich, Yaroslavl district, Russia & N 57.32 E 38.20 & Seeds (YS) \\
\hline $\begin{array}{c}\text { Saransk, Republic of Mordovia, } \\
\text { Russia }\end{array}$ & N 54.18 E 45.17 & Seeds (MS) \\
\hline \multicolumn{3}{|c|}{ Slovakia } \\
\hline $\begin{array}{c}\text { Nitra, Slovakia } \\
\text { Nova Bana, Slovakia }\end{array}$ & $\begin{array}{ll}\mathrm{N} 48.18 & \text { E } 18.05 \\
\mathrm{~N} 48.25 & \text { E } 18.38\end{array}$ & $\begin{array}{l}\text { Seeds (NiS) } \\
\text { Seeds (NoS) }\end{array}$ \\
\hline
\end{tabular}



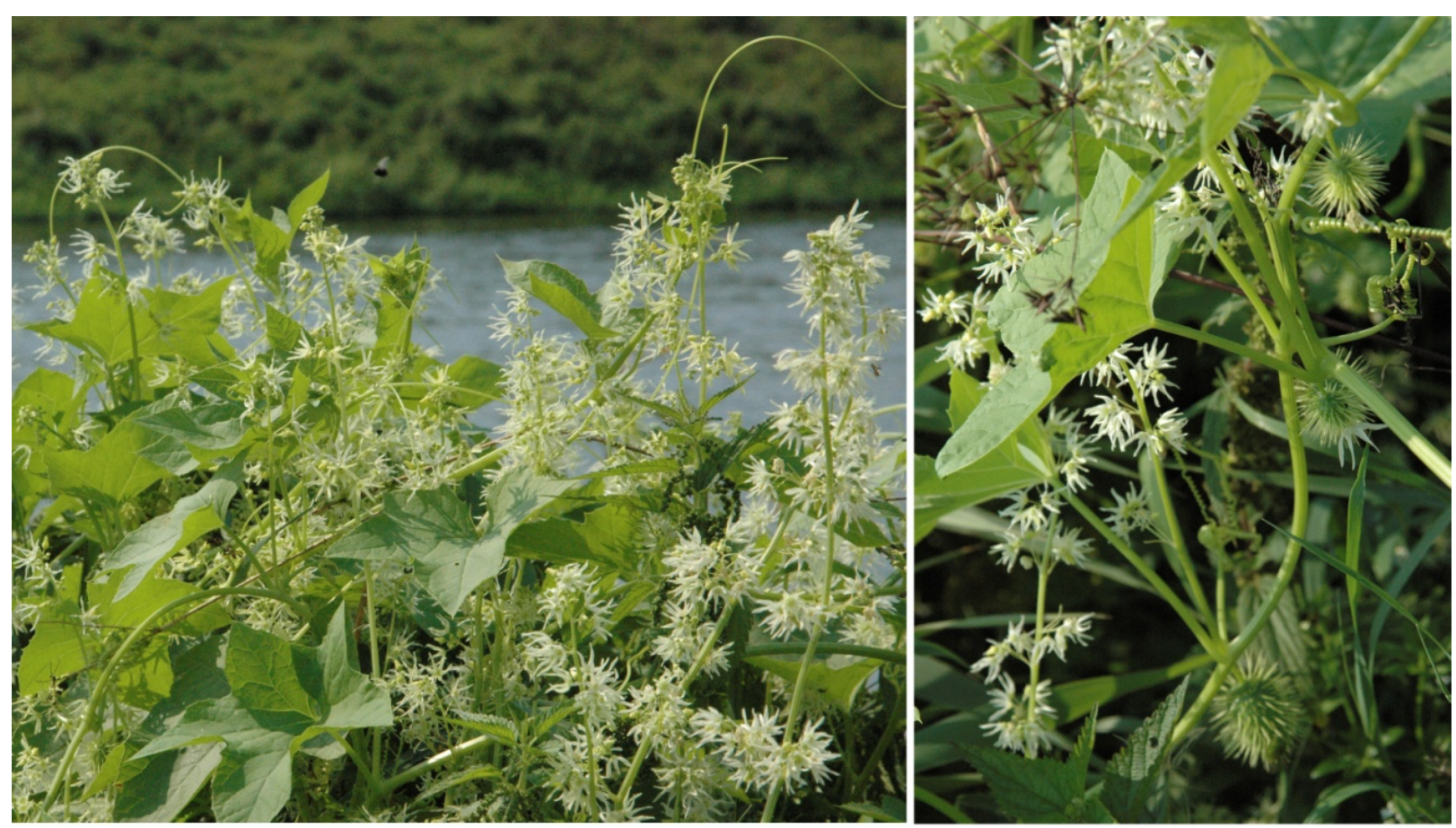

Figure 1 Invasive populations of Echinocystis lobata (Mich.) Torr. et Gray.
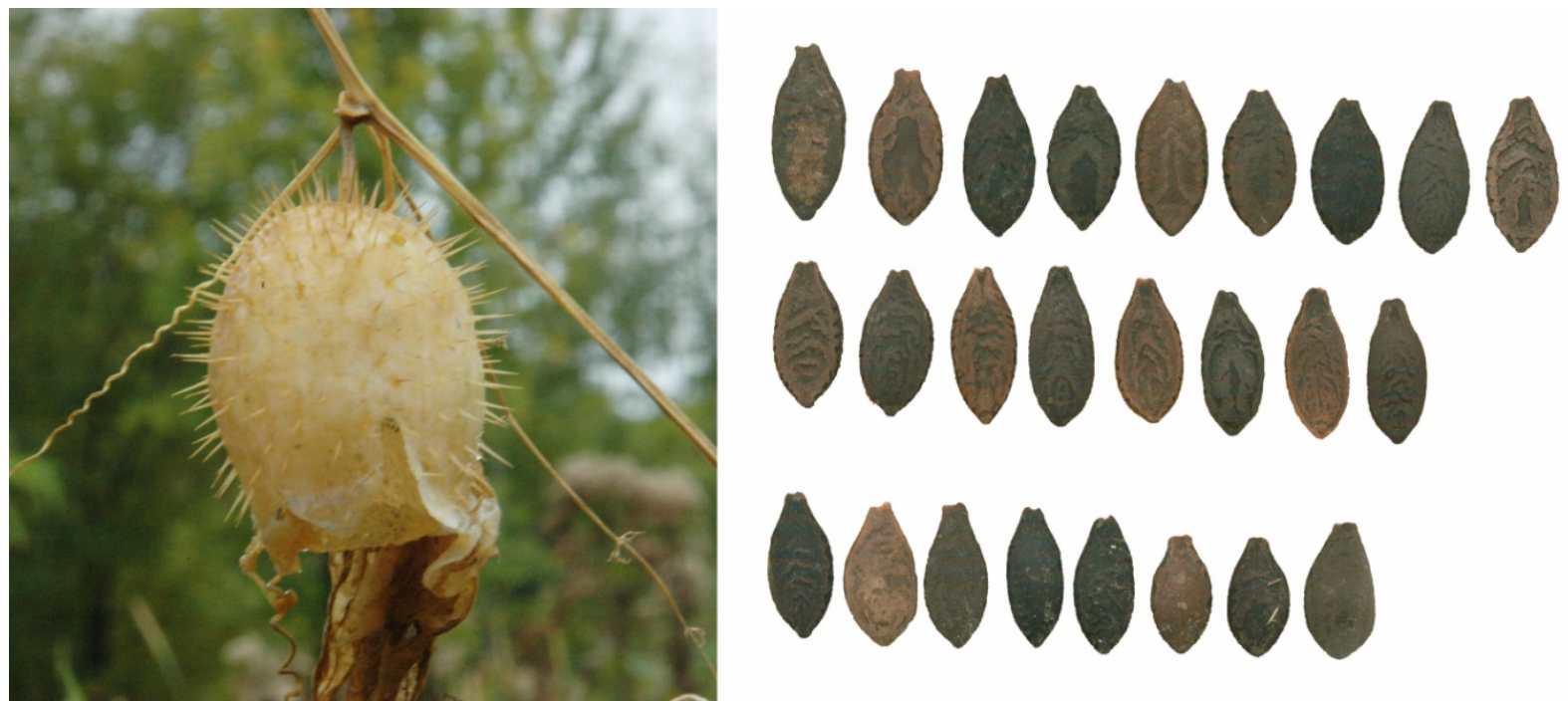

Figure 2 Fruit and seeds of Echinocystis lobata (Mich.) Torr. et Gray (each seed has been collected from single individual).

\section{Description of the Experiment}

Sample preparation:

a) for the antioxidant activity measurements: $0.2 \mathrm{~g}$ of dried plant raw material was extracted with $20 \mathrm{~mL}$ of $80 \%$ ethanol for 2 hours. After centrifugation at $4000 \mathrm{~g}$ (Rotofix 32 A, Hettich, Germany) for $10 \mathrm{~min}$, the supernatant was used.

b) for the polyphenols and flavonoids measurements: the air-dried plant material was mechanically ground to a homogeneous powder in a laboratory mill. All Echinocystis samples weighing approximately $0.7 \mathrm{~g}$ (weighed to the nearest $0.0001 \mathrm{~g}$ ) were extracted in 15 $\mathrm{ml}$ of a mixture of $90 \%$ ethanol and $1 \%$ chloric acid in a reflux condenser water bath at $60{ }^{\circ} \mathrm{C}$ for $30 \mathrm{~min}$. The obtained extract was passed through a $0.25 \mu \mathrm{m}$ filter.
The extraction was repeated three times. The total volume of the extract is $45 \mathrm{ml}$, stored in a dark place at $4{ }^{\circ} \mathrm{C}$ until analysis.

Number of samples analyzed: A total of 55 samples were analyzed.

\section{Determination of antiradical activity}

The antiradical activity was measured by the 2.2diphenyl-1-picrylhydrazyl (DPPH·) method according to Brand-Williams, et al. (1995). This test is based on the reaction of radical discoloration (the color of the radical solution is purple). The procedure of determination of optical density was measured with a spectrophotometer (Genesys 20 UV-VIS, USA) at wavelength $515 \mathrm{~nm}$. Investigated plants were dried at room temperature and 
powdered. Dry mass $(1 \mathrm{~g})$ of plant raw material was mixed with $25 \mathrm{ml}$ of solvent. Extraction was carried out with methanol, ethanol, and water for 12 hours with constant stirring on a shaker. Obtained extracts were filtrated (Whatman No. 1) and $0.1 \mathrm{ml}$ of antioxidant solution was added to $3.9 \mathrm{ml}$ of methanol DPPH solution $(25 \mathrm{mg}$ of radical per $100 \mathrm{ml}$ of methanol with further dilution). The optical density of the solution was measured immediately and after adding a sample. The incubation for 10 minutes was in the dark. Obtained results were calculated in percentage by using the following equation (1):

$$
\% \operatorname{Inh}=\frac{A_{0}-A_{1}}{A_{0}} \times 100
$$

where:

$\mathrm{A}_{0}$ - absorbance of control reaction;

$\mathrm{A}_{1}$ - absorbance in presence of the sample.

\section{Determination of Total Phenolic Content (TPC)}

The total phenolic content was determined using the Folin-Ciocalteu procedure by using gallic acid as standard. The crude extract $(40 \mu \mathrm{g})$ was mixed with Folin Ciocalteu reagent $(200 \mu \mathrm{L})$ and distilled water $(3.16 \mathrm{~mL})$. The mixture was left between $30 \mathrm{sec}$ to $8 \mathrm{~min}$ before being added with $20 \%$ sodium carbonate $(600 \mu \mathrm{L})$. The mixture was kept at $20^{\circ} \mathrm{C}$ for 2 hours and the absorbance was read at $765 \mathrm{~nm}$ using a Spectrophotometer Spekol 1300 (Analytik Jena). The TPC values were calculated using a gallic acid calibration curve within the range $0-2000 \mathrm{mg} / \mathrm{L}(\mathrm{R} 2=0.9982)$. The results were expressed as gallic acid equivalents (GAE) $\mathrm{mg} / \mathrm{g} \mathrm{dw}$ vegetal product. All samples were analyzed in triplicate.

\section{Determination of Total Flavonoid Content (TFC)}

The total flavonoid content of the methanol extract was determined using the aluminium chloride colorimetric method with quercetin [2] and rutin [3] as standard. The crude extracts $(1 \mathrm{mg})$ were diluted with water $(4 \mathrm{~mL})$ in a $10 \mathrm{~mL}$ volumetric flask. Initially, 5\% sodium nitrate solution $(0.3 \mathrm{~mL})$ was added to each volumetric flask then $10 \%$ aluminium chloride $(0.3 \mathrm{~mL})$ was added into the flask and followed by $1.0 \mathrm{M} \mathrm{NaOH}(2 \mathrm{ml})$. Water $(2.4 \mathrm{~mL})$ was then added to the flask and mixed well. The absorbance of the mixture was kept at $22{ }^{\circ} \mathrm{C}$ for 20 minutes and the absorbance was read at $430 \mathrm{~nm}$ (quercetin) and kept at 22 ${ }^{\circ} \mathrm{C}$ for 40 minutes and the absorbance was read at 415 (rutin). TFC values were determined as quercetin equivalents (QE) $\mathrm{mg} / \mathrm{g}$ and rutin equivalents (RE) $\mathrm{mg} / \mathrm{g} \mathrm{dw}$ vegetal product. All samples were analyzed in triplicate.

\section{Statistical Analysis}

The statistically treated data are given as the arithmetical mean values and their standard errors. Data were submitted ANOVA and differences between means compared through the Tukey-Kramer test $(p<0.05)$.

\section{RESULTS AND DISCUSSION}

Echinocystis lobata is an annual vine with stems that can be as long as $6 \mathrm{~m}$ (Vinogradova, 2006) and which climb, with the help of coiling, branched tendrils, over shrubs and fences or trail across the ground. The leaves are alternate with long petioles and five palmate lobes. The flowers are monoecious, with separate male and female blooms on the same plant. The male flowers are in long-stemmed, upright panicles. Each flower has a white, or greenish-yellow, corolla with six slender lobes and a single central stamen with a yellow anther. The female flower has a single stigma with the spiky globular inferior ovary. The fruit is a prickly, inflated capsule up to $5 \mathrm{~cm}$ long with two pores and four seeds. It persists all winter and then opens at the bottom, liberating the seeds.

The seed of Echinocystis lobata, collected from a single individual, has its shape, color, and seed coat pattern (like a person's fingerprints). Only seed weight and size vary. Seeds of 17 discrete variations (phenotypes) have been identified, occurring both in the natural and in secondary habitat. The spermoderm texture can be smooth or wrinkled, with or without a pattern. The shape of the semen varies from rounded to oval or, less frequently, lanceolate. Spermoderm coloring may be black, brown, or grey, with or without a stripe along the lateral seam. Spermoderm pattern may be marbled or spotted, in the latter case, the spots may be rounded, triangular, or shapeless. In all populations, oval-shaped seeds with wrinkled patterned spermoderm prevailed (Vinogradova, et al., 2010). High variability in seed size and coloration has also been noted by other researchers (Golivets, 2014).

The biochemical composition of Echinocystis seed oil has been best studied. Linoleic, oleic, palmitic, stearic, and linolenic acids, as well as phytosteroids (spinasterol, sigmastadiene) and glycoside of echinocystic acid, were isolated in seed oil (Sokolov, 1986). Our previous studies (Shelepova, et al., 2016) have also shown that the component composition of Echinocystis seed oil from populations of the secondary distribution range of Central Russia is almost similar to that of plants from North American populations. The seeds of Echinocystis lobata are of interest for their possible use in phytotherapy. They can be used for the prevention of some diseases and, in particular, as an anti-inflammatory component, as they contain up to $1 \%$ of triterpene saponins, up to $0.1 \%$ of flavonoids, and up to $40 \%$ of oil. Fatty acid oil composition is represented by almost $60 \%$ linoleic acid (Shelepova and Vinogradova, 2016, 2017).

As a result, numerous reports are dedicated to the study of useful properties of invasive plants, among which different biological activities. The antioxidant activity of these plants demonstrated valuable results comparing with widely used species (Guzzetti, et al., 2017; Sari, et al., 2018; Maema, Potgieter and Samie, 2019). Several studies showed that the content of polyphenol compounds of invasive plants had higher values than native (Kim and Lee, 2011). 


\section{Determination of antiradical activity}

As we expected, samples of Echinocystis contain the same high levels of bioactive substances as other invasive species. The antiradical activity of alcohol extracts for all specimens was quite high. The free radical scavenging activity in the leaf extracts had $60.93 \pm 2.66 \%$ (methanol extracts), $37.30 \pm 0.60 \%$ (ethanol extracts), and 26.47 $\pm 1.60 \%$ (water extracts) (Figure 3). The same characteristic in the inflorescences was higher in alcohol extracts: $76.93 \pm 0.92 \%$ (methanol extracts), $49.48 \pm 2.18 \%$ (ethanol extracts) but was lower in water extracts 13.46 $\pm 1.22 \%$.

Rodge and Biradar (2017) found in ethanol extracts of other Cucurbitaceae the antiradical activity for the following species: Coccinia grandis L. fruits (72.14\%) and leaves (18.40\%), Lagenaria siceraria (Molina) Standl. fruits $(23.20 \%)$ and leaves $(14.85 \%)$, Thrichosanthes tricuspidata Lour. fruits $(65.0 \%)$ and leaves $(54.0 \%)$, Diplocyclos palmatus (L.) Jeffrey fruits (60.33\%), and leaves $(22.33 \%)$, Cucumis setosus Cogn. fruits (59.66\%) and leaves $(29.26 \%)$. Similar to our data, closely related above species from the Cucurbitaceae family accumulate more phenol in the fruit than in the leaves. Echinocystis fruits accumulate fewer substances with antiradical activity than Coccinia grandis, Thrichosanthes tricuspidata, Diplocyclos palmatus, and Cucumis setosus, but more than Lagenaria siceraria (49\% versus 23\%). However, it should not be forgotten that all these species, already actively used for medicinal purposes, grow mainly in subtropical or tropical climates, whereas Echinocystis is a temperate plant.

\section{Determination of Total Phenolic Content (TPC)}

There are about 8000 plant phenolics in nature. They are one of the main groups of compounds working as primary antioxidants or free radical scavengers. TPC is almost independent of the climatic conditions of the plant habitats and varies from 12.9 to $21.2 \mathrm{mg}$ GAE/100g in Russian invasive populations and from 17.5 to 19.9 in invasive populations in Slovakia (Table 2).

Moreover, mature fruit, immature fruit, and seed also do not differ in this indicator, a comparison for which has been made for the Zvenigorod population. The highest TPC was found in seeds of Ys (Uglich, Yaroslavl district,

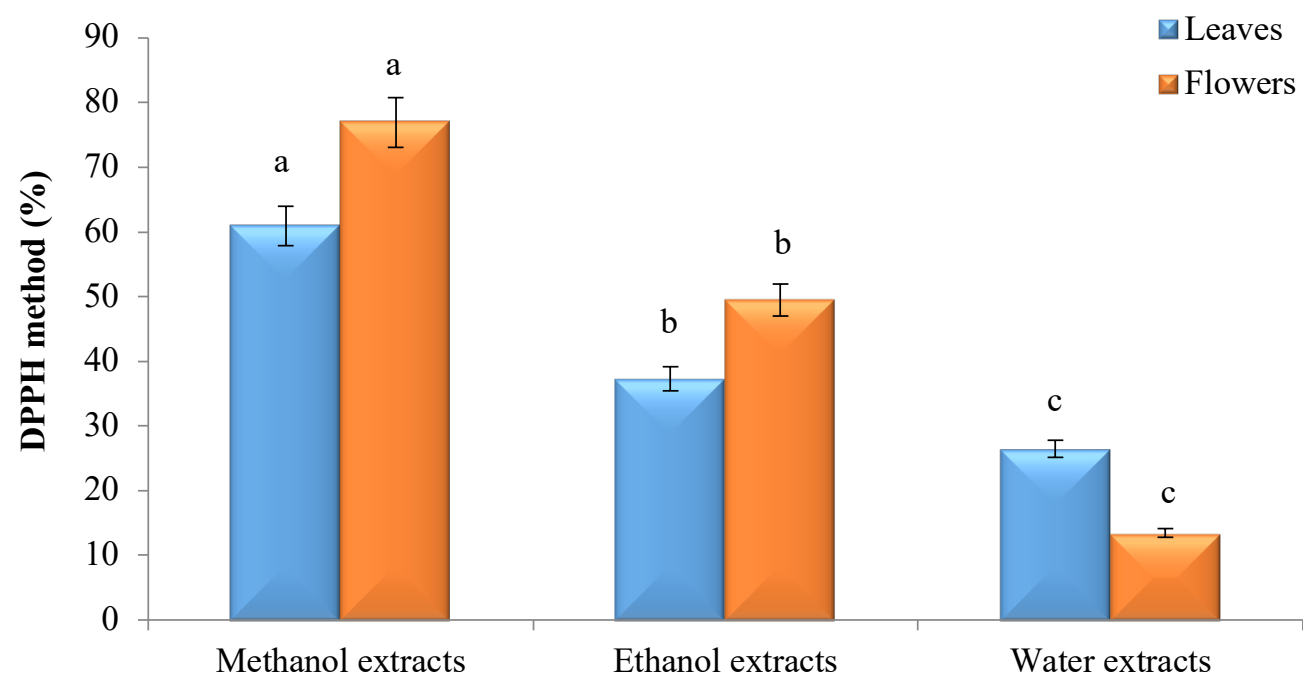

Figure 3 Antioxidant activity of leaves and flowers of Echinocystis lobata (Mich.) Torr. et Gray.

Note: (DPPH method, \%). Means in columns followed by different letters are different at $p<0.05$.

Table 2 Total Phenolic Content and Total Flavonoid Content in studied samples of Echinocystis lobata (Mich.) Torr. et Gray.

\begin{tabular}{lccc}
\hline & $\begin{array}{c}\text { Sample } \\
\text { (according Table 1) }\end{array}$ & Total Phenolic Content & \multicolumn{2}{c}{ Total Flavonoid Content (TFC) } \\
\cline { 3 - 4 } (TPC), mg GAE/100g) & Quercetin, mg QE/g & Rutin, mg RE/g \\
\hline ZF & \multicolumn{3}{c}{ Russia } \\
ZFS & $15.33 \pm 1.21 \mathrm{c}$ & $266.52 \pm 2.11 \mathrm{a}$ & $1264.85 \pm 3.17 \mathrm{a}$ \\
ZS & $12.93 \pm 0.87 \mathrm{~d}$ & $10.64 \pm 0.51 \mathrm{e}$ & $242.78 \pm 1.12 \mathrm{~d}$ \\
TS & $15.32 \pm 0.91 \mathrm{c}$ & $80.14 \pm 0.77 \mathrm{~d}$ & $297.14 \pm 1.20 \mathrm{c}$ \\
MS & $15.62 \pm 0.93 \mathrm{c}$ & $10.92 \pm 0.45 \mathrm{e}$ & $74.75 \pm 0.83 \mathrm{e}$ \\
KS & $17.08 \pm 1.05 \mathrm{~b}$ & $128.79 \pm 0.91 \mathrm{c}$ & $440.77 \pm 1.57 \mathrm{~b}$ \\
YS & $19.21 \pm 0.95 \mathrm{a}$ & $84.38 \pm 0.71 \mathrm{~d}$ & $312.86 \pm 1.21 \mathrm{c}$ \\
\hline \multicolumn{3}{c}{ Slovakia } \\
\hline NiS & $21.19 \pm 1.17 \mathrm{a}$ & $164.86 \pm 0.93 \mathrm{~b}$ & $470.20 \pm 1.62 \mathrm{~b}$ \\
NoS & $17.46 \pm 1.01 \mathrm{~b}$ & $227.17 \pm 1.63 \mathrm{a}$ & $779.54 \pm 1.54 \mathrm{a}$ \\
\hline
\end{tabular}

Note: Values are expressed as the mean $\pm \mathrm{SD}(\mathrm{n}=3)$. Means in columns followed by different letters are different at $p<0.05$. 
Russia), whereas the lowest was found in seeds of Zs (Zvenigorod, Moscow district, Russia).

The TPC levels obtained are significantly different from those found in dry unripe fruit with milk seeds of Echinocystis lobata. These results highlight the significant differences in total phenolic content among different organs of Echinocystis lobata. It seems to suggest that seeds from Echinocystis lobata may be the best source to obtain extracts with high TPC.

\section{Determination of Total Flavonoid Content (TFC)}

In contrast, the TFC indicator demonstrates a difference in flavonoid content between mature fruit, immature fruit, and seeds. Unripe fruit contains the least flavonoids (10.6 $\mathrm{mg} \mathrm{QE} / \mathrm{g}$ and $242.8 \mathrm{mg} \mathrm{RE} / \mathrm{g}$ ), seeds contain somewhat more flavonoids (80.1 mg QE/g and $297.1 \mathrm{mg} \mathrm{RE} / \mathrm{g}$ ). Most flavonoids are accumulated in the dried fruits. As for quercetin, this index $(266.5 \mathrm{mg} \mathrm{QE} / \mathrm{g})$ is 26 times higher than in unripe fruits and 3 times higher than in seeds. For rutin, this index ( $1264.8 \mathrm{mg} \mathrm{RE} / \mathrm{g}$ ) is 5 times higher than in unripe fruits and 4 times higher than in seeds.

There is also a difference in flavonoid accumulation depending on where the seeds are harvested. Seeds collected in Slovakia contain significantly more flavonoids than seeds collected in Central Russia. In seeds collected in Russia, the TFC for quercetin ranges from 10.9 to 164.9 $\mathrm{mg}$ QE/g, while in Slovak populations it ranges from 173.2 to $227.2 \mathrm{mg} \mathrm{QE} / \mathrm{g}$. The TFC value for rutin ranges from 74.7 to $470.2 \mathrm{mg} \mathrm{RE} / \mathrm{g}$ for Russian populations, while in Slovak populations it is much higher and ranges from 538.7 to $779.5 \mathrm{mg} \mathrm{RE} / \mathrm{g}$.

As we suggested, the flavonoid content of invasive Echinocystis is higher than that of many other plants. For example, the TFC of Manilkara zapota (L.) P Royen seeds are 97.2- 116.1 mg RE/g (Shafii, et al., 2017) compared to 538.7-779.5 for the seed of Echinocystis lobata in Slovakia. The TFC values in Moringa oleifera seeds (Ghafar, et al., 2017) were 99.72 (mg QE/g of extract weight), which is also significantly lower than that of Echinocystis. Abifarin, et al. (2019) found TFC of methanol extracts for wild vegetable Cucumis africanus in fruits and leaves 20.63 and $228.96 \mathrm{mg} \mathrm{QE} / \mathrm{g}$, respectively, and TPC 17.46 and $43.31 \mathrm{mg} \mathrm{GAE} / \mathrm{g}$.

\section{CONCLUSION}

The fruits and seeds of Echinocystis lobata are of interest for further investigation into their possible use in phytotherapy. They can be used for the prevention of several diseases and, in particular, as an anti-inflammatory component as they contain up to $1 \%$ triterpene saponins, up to $40 \%$ oil, whose fatty acid composition is represented by almost $60 \%$ linoleic acid, and up to $0.1 \%$ flavonoids. Echinocystis is superior to many other plants in terms of the total amount of flavonoids contained in its fruits and seeds. The dried fruits contain more flavonoids than the seeds. Seeds from Slovak populations of Echinocystis have a higher flavonoid content than those from Russian populations. The results demonstrated that Echinocystis lobata can be a valuable raw material resource for the bioeconomy and there is the possibility of its wider application in the future.

\section{REFERENCES}

Abifarin, T. O., Afolayan, A. J., Otunola, G. A. 2019. Phytochemical and antioxidant activities of Cucumis africanus L.f.: a wild vegetable of South Africa. Journal of Evidence-Based Integrative Medicine, vol. 24, p. 1-8. https://doi.org/10.1177/2515690X19836391

Atanassova, M., Georgieva, S., Ivancheva, K. 2011. Total phenolic and total flavonoid contents, antioxidant capacity and biological contaminants in medicinal herbs. Journal of the University of Chemical Technology and Metallurgy, vol. 46, no. 1, p. 81-88.

Budantsev, A. L., Lesiovskaya, E. E. 2014. Dikorastushchiye poleznyye rasteniya Rossii [Useful wild plants in Russia]. St. Petersburg: State Chemical Pharmaceutical Academy. 663 p. (In Russian)

Burton, T., Dunlap, T., Dong, H., Li, G., Bolton, J., Soejarto, D., van Breemen, R. B. 2015. American Indian botanicals: possible alternatives to hormone therapy during menopause. Planta Med., vol. 81 - PM13. https://doi.org/10.1055/s-0035-1556326

Coxworth, E. C. M. 1965. Oil and protein content, and oil composition of seeds of some plants of the Canadian praires. J. of the Amer. Oil Chemist's Society, vol. 42, no.10, p. 891894. https://doi.org/10.1007/BF02541188

Ghafar, F., Nazrin, T. N. N. T., Salleh, M. R. M. S, Hadi, N. N, Ahmad, N., Hamzah, A. A., Yusof, Z. A. M., Azman, I. N. 2017. Total phenolic content and total flavonoid content in Moringa oleifera seed. Science Heritage Journal, Galeri Warisan Sains (GWS), vol. 1, no. 1, p. 23-25. https://doi.org/10.26480/gws.01.2017.23.25

Gillard, D. F., Walton D. C. 1976. Abscisic acid metabolism by a cell-free preparation from Echinocystis lobata liquid endosperm. Plant Physiol., vol. 58, p. 790-795. https://doi.org/10.1104/pp.58.6.790

Golivets, M. 2014. Variation quantitative seed traits of Echinocystis lobata (Michx.) Torr. et Gray (Cucurbitaceae). Modern Phytomorphology, vol. 4. p. 43-44. https://doi.org/10.13140/2.1.5068.6084

Grygorieva, O., Klymenko, S., Vergun, O., Mňahončakova, E., Brindza, J., Terentjeva, M., Ivanišova, E. 2020. Evaluation of the antioxidant activity and phenolic content of Chinese quince (Pseudocydonia sinensis Schneid.) fruit. Acta Sci. Pol. Technol. Aliment., vol. 19, no. 1, p. 25-36. https://doi.org/10.17306/J.AFS.2020.0738

Grygorieva, O., Kucharska, A. Z., Piórecki, N., Klymenko, S., Vergun, O., Brindza, J. 2018. Antioxidant activities and phenolic compounds in fruits of various genotypes of American persimmon (Diospyros virginiana L.). Acta Sci. Pol. Technol. Aliment., vol. 17, no. 2, p. 117-124. https://doi.org/10.17306/J.AFS.0544

Guzzetti, L., Galimberti, A., Bruni, I., Magoni, C., Ferri, M., Tassoni, A., Sangiovanni, E., Dell'Agli, V., Labra, M. 2017. Bioprospecting on invasive plant species to prevent seed dispersal. Scientific Reports, vol. 7, p. 13799. https://doi.org/10.1038/s41598-017-14183-5

Horčinová Sedláčková, V., Grygorieva, O., FatrcováŠramková, K., Vergun, O., Vinogradova, Y., Ivanišová, E., Brindza, J. 2018. The morphological and antioxidant characteristics of inflorescences within wildgrowing genotypes of elderberry (Sambucus nigra L.). Potravinarstvo Slovak Journal of Food Sciences, vol. 12, no. 1, p. 444-453. https://doi.org/10.5219/919

Horčinová Sedláčková, V., Grygorieva, O., Vergun, O. M., Vinogradova, Y., Brindza, J. 2019. Comparison of selected characteristics of cultivars and wild-growing genotypes of 
Sambucus nigra in Slovakia. Biosystems Diversity, vol. 27, p. 56-61. https://doi.org/10.15421/011909

Ielciu, I., Hanganu, D., Păltinean, R., Vlase, L., Frédérich, M., Gheldiu, A., Benedec, D., Crişan, G. 2018. Antioxidant capacity and polyphenolic content of the Echinocystis lobata (Michx.) Torr. et A.Gray flowers. Pak. J. Pharm. Sci., vol. 31, no. 2, p. 677-683.

Ielciu, I., Vlase, L., Frédérich, M., Hanganu, D., Păltinean, R., Cieckiewicz, E., Olah, N., Gheldiu, A., Crişan, G. 2017. Polyphenolic profile and biological activities of the leaves and aerial parts of Echinocystis Lobata (Michx.) Torr. et A. Gray (Cucurbitaceae). Farmacia, vol. 65, no. 2, p. 179-183.

Ivanišová, E., Blašková, M., Terentjeva, M., Grygorieva, O., Vergun, O., Brindza, J., Kačániová, M. 2020. Biological properties of sea buckthorn (Hippophae rhamnoides L.) derived products. Acta Sci. Pol. Technol. Aliment., vol. 19, no. 2, p. 1-11. https://doi.org/10.17306/J.AFS.2020.0809

Ivanišová, E., Grygorieva, O., Abrahamová, V., Schubertova, Z., Terentjeva, M., Brindza, J. 2017. Characterization of morphological parameters and biological activity of jujube fruit (Ziziphus jujuba Mill.). Journal of Berry Research, vol. 7, no. 4, p. 249-260. https://doi.org/10.3233/JBR-170162

Kim, Y. O., Lee, E. J. 2011. Comparison of phenolic compounds and the effects of invasive and native species in East Asia: Support for the novel weapons hypothesis. Ecological Research, vol. 26, no. 1, p. 87-94. https://doi.org/10.1007/s11284-010-0762-7

Klymenko, S., Grygorieva, O., Brindza, J. 2017. Less known species of fruit crops. Nitra: Slovak University of Agriculture in Nitra, 104 p. https://doi.org/10.15414/2017.fe$\underline{9788055217659}$

Krauze-Baranowska, M., Cisowski, W. 1996. Flavonoids from Echinocystis lobata and Echinocystis wrightii. Polish Journal of Chemistry, vol. 70, no. 4, p. 430-436.

Maema, L. P., Potgieter, M. J., Samie, A. 2019. Dataset on preliminary phytochemical analysis and antioxidant activity of selected invasive alien plant species used in the treatment of sexually transmitted infections in Waterberg district, South Africa. Data in brief, vol. 25, p. 104281. https://doi.org/10.1016/j.sajb.2019.01.012

Melymuka, M., Junge, C., Burnham, R. 2005. Echinocystis lobata. Plant Diversity, vol. 64, no. 1, p. 1-4.

Monka, A., Grygorieva, O., Chlebo, P., Brindza, J. 2014. Morphological and antioxidant characteristics of quince (Cydonia oblonga Mill.) and Chinese quince fruit (Pseudocydonia sinensis Schneid.). Potravinarstvo Slovak Journal of Food Sciences, vol. 8, p. 333-340. https://doi.org/10.5219/415

Panosyan, A. G. 1985. Vliyanie kukurbitacinov brionii na biosintez ejkozanoidov $\mathrm{v}$ lejkocitah cheloveka [Effect of bryonia cucurbitacin on eicosanoid biosynthesis in human leukocytes]. Bioorganic chemistry, vol. 11, no. 2, p. 264-269. (In Russian)

Richardson, D. M., Pyšek, P. 2006. Plant invasions: Merging the concepts of species invasiveness and community invisibility. Prog. Phys. Geogr., vol. 30, no. 3, p. 409-431. https://doi.org/10.1191/0309133306pp490pr

Rodge, S., Biradar, S. D. 2017. Antioxidant activity of some medicinal plants of family Cucurbitaceae. Worlds Journal of Pharmaceutical Research, vol. 6, no. 4, p. 946-951. https://doi.org/10.20959/wjpr20174-8097

Sari, N. M., Kuspadini, H., Amirta, R., Kusuma, I. W. 2018. Antioxidant activity of an invasive plant, Melastoma malabathricum and its potential as herbal tea product. $1^{\text {st }}$ International Conference on Tropical Studies and its
Application. Earth and Environmental Science, vol. 144, p. 012029. https://doi.org/10.1088/1755-1315/144/012029

Shafii, Z. A., Basri, M., Malek, E. A., Ismail, M. 2017. Phytochemical and antioxidant properties of Manilkara zapota (L.) P. Royen fruit extracts and its formulations for cosmeceutical application. Asian Journal of Plant Science and Research, vol. 7, no. 3, p. 29-41.

Shelepova, O. V., Vinogradova, J. K. 2017. Chemical composition of oil in the seed of Echinocystis lobata (Mich.) Torr. et Gray. Skvortsovia, vol. 3, no. 2, p. 88-90.

Shelepova, O. V., Vinogradova, Yu. K., Vergun, O., Grygorieva, O. V., Brindza, J. 2020. Assessment of flavonoids and phenolic compound accumulation in invasive Solidago canadensis L. in Slovakia. Potravinarstvo Slovak Journal of Food Sciences, vol. 14, p. 587-594. https://doi.org/10.5219/1378

Shelepova, O., Kuklina, A., Vinogradova, Yu. 2016. Seeds of Echinocystis lobata (Mich.) Torr. et Gray, Cucurbitaceae as a promising pharmacological agent. Agrobiodiversity for improving nutrition, health and life quality. Nitra, p. 416-420.

Shelepova, O., Vinogradova, Yu.2016. Oil Composition of the Seeds of Echinocystis lobata (Mich.) Torr. et Gray. International Symposium on Natural Products for the Future. Tokushima, Bunri University, p. 110.

Sokolov, P. D. 1986. Rastitel'nye resursy SSSR [Plant Resources of the USSR]. Leningrad: Nauka. 336 p.

Stachowiak, D., Polanowski, A., Grazyna, B., Wilusz, T. 1996. Isolation and amino-acid sequence of two inhibitors of serine proteinases, members of the squash inhibitor family, from Echinocystis lobata seeds. Acta Biochim Pol., vol. 43, no. 3, p. 507-514. https://doi.org/10.18388/abp.1996 4484

Szot, I., Zhurba, M., Klymenko, S. 2020. Pro-health and functional properties of goji berry (Lycium spp.). Agrobiodiversity for Improving Nutrition, Health and Life Quality, vol. 4, p. 134-145. https://doi.org/10.15414/agrobiodiversity.2020.25858246.134-145

Touihri, I., Kallech-Ziri, O., Boulila, A., Fantasi, S., Marrakchi, N., Luis, J., Belgacem, N. 2019. Ecballium elaterium (L.) A. Rich. seed oil: Chemical composition and antiproliferative effect on human colonic adenocarcinoma and fibrosarcoma cancer cell lines. Arabian Journal of Chemistry, vol. 12, no. 8, p. 2347-2355. http://dx.doi.org/10.1016/j.arabjc.2015.02.023

Vinogradova, Y. K. 2006. Etapy formirovaniya vtorichnogo areala $\mathrm{i}$ izmenchivost' invazionnyh populyacij ekhinocistisa shipovatogo [Stages of secondary range formation and variability of invasive populations of Echinocystis]. Bulleten Glavnogo botan. sada, vol. 192, p. 8-23. (In Russian)

Vinogradova, Y. K., Mayorov, S. R., Choroon, L. V. 2010. Black book of flora of the Middle Russia. Moscow, Russia: Geos Press, 512 p.

Vinogradova, Y., Vergun, O., Grygorieva, O., Ivanišová, E., Brindza, J. 2020. Comparative Analysis of Antioxidant Activity and Phenolic Compounds in the Fruits of Aronia spp. Potravinarstvo Slovak Journal of Food Sciences, vol. 14, p. 393-401. https://doi.org/10.5219/1360

\section{Funds:}

This work was supported by grants Bilateral Scholarship of the Ministry of Education, Science, Research and Sport (Slovak Republic), SAIA and Visegrad Fund. The work was carried out in accordance with the MBG RAS Research Project № 19-119080590035- 9. 


\section{Acknowledgments:}

The publication was prepared with the active participation of researchers in international network AgroBioNet, as a part of international program "Agricultural Biodiversity to Improve Nutrition, Health and Quality of Life" within the project ITMS 25110320104 "Innovation of Test Methods and Procedures for the Detection of Sources of Bioactive Substances for the Improvement of Health and Quality of Life".

\section{Conflict of Interest:}

The authors declare no conflict of interest.

\section{Ethical Statement:}

This article does not contain any studies that would require an ethical statement.

\section{Contact Address:}

Yulia Vinogradova, N. V. Tsitsin Main Botanical Garden of Russian Academy of Sciences, Botanicheskaya, 4, 127276 Moscow, Russia, Tel.: +74999779136,

E-mail: gbsad@mail.ru

ORCID: https://orcid.org/0000-0003-3353-1230

Olga Shelepova, N. V. Tsitsin Main Botanical Garden of Russian Academy of Sciences, Botanicheskaya, 4, 127276 Moscow, Russia, Tel.: +74999779136,

E-mail: shelepova-olga@mail.ru

ORCID: https://orcid.org/0000-0003-2011-6054

Olena Vergun, M. M. Gryshko National Botanical Garden of the NAS of Ukraine, Cultural Flora Department, Timiryazevska 1, 04014, Kyiv, Ukraine, Tel.: +380975398541,

E-mail: olenavergun8003@gmail.com

ORCID: https://orcid.org/0000-0003-2924-1580

*Olga Grygorieva, M. M. Gryshko National Botanical Garden of the NAS of Ukraine, Department of Fruit Plants Acclimatisation, Timiryazevska 1, 04014, Kyiv, Ukraine, Tel.: +380671988082,

E-mail: olgrygorieva@gmail.com

ORCID: https://orcid.org/0000-0003-1161-0018

Jan Brindza, Slovak University of Agricultural in Nitra, Faculty of Agrobiology and Food Resources, Institute of Biological Conservation and Biosafety, Trieda Andreja Hlinku 2, 94976 Nitra, Slovakia, Tel: +421376414787, E-mail: Jan.Brindza@uniag.sk

ORCID: https://orcid.org/0000-0001-8388-8233

Corresponding author: * 